\title{
PROJECT: SCREENPLAY GOING HOME
}

Katarina, S. ${ }^{1}$ and Basuki, R. ${ }^{2}$

1,2English For Creative Industry, Faculty of Letters, Petra Christian University, Siwalankerto 121-131, Surabaya 60236, East Java, INDONESIA

E-mails:m11412032@john.petra.ac.id; rbasuki@peter.petra.ac.id

\begin{abstract}
This paper explained the process and the result of my final project which is a screenplay entitled Going Home. The screenplay is about Dahlia, a thirteen-year-old girl who was born and grew up in Australia. Then, she has to return to Jakarta, Indonesia and continue her education in Indonesia. She has an assignment about history of Indonesia. She needs to write one of heroic history of Indonesia with her own words and write her reflection about it. Once, she goes to Surabaya for a holiday and stays at Majapahit Hotel Surabaya. In the hotel, she experiences the past life about several historical moments by going back and forth to a past life and present life. After experiencing it, she can feel and understand the spirit of the Indonesian revolutionary heroes. She respects Indonesia heroes more. Also, she can encourage her friends to love Indonesia better and to blend in diverse group of ethnics as strong and one Indonesian who support to improve Indonesia. I would like to show that young generations are now lack the spirit to build their country. They forget to become one; One Land, One Nation, One Language. This creative work focuses on how history of Indonesia can help young generations to gain the spirit of Indonesian revolutionary heroes to love and improve Indonesia. To put this issue into a form of entertainment, I decided to make a screenplay which type of genre is adventure fantasy.
\end{abstract}

Keywords: Adventure, Fantasy, Nationalism, Young Spirit

\section{INTRODUCTION}

Once, I had taken a screenplay writing subject in the fifth semester, I knew that I love to write a screenplay. I have been exposed to films with many genres by my parents since my childhood. This makes me have deep interest in films. That is why I decided to write a screenplay for my final project. I believe in myself that I will be able to contribute more by doing my final project related to Indonesian films.

In my project, I want to use film to deal with the problems of young spirit in Indonesia. After Indonesian independence in 1945 , we, as the next generation, are expected to keep what the Indonesian heroes had fought for. To keep the spirit of nationalism that they had is indeed the biggest challenge for Indonesian people, especially Indonesian youngsters in this era. However, as times goes by, Indonesian youngsters forget the pledge, "Satu Nusa, Satu Bangsa, Satu Bahasa," that Indonesian heroes had. The pledge which literally translates to "One Land, One Nation, One Language" means that even though Indonesia has many islands and provinces, they are still one body which is Indonesia. Even though Indonesia has many ethnic groups, they are still one nation which is Indonesian. Even though every ethnic group has its own language and dialect, they still use one language which is Bahasa Indonesia (PojokPitu, 2015).

Based on the facts that I get from news, Young Indonesians are now lack the spirit to build the country; instead, they use their energy to do shameful actions. The situation has been upside down; back then Indonesian youth carried weapons to fight against colonializers, but now Indonesian youngsters use their weapons to attack one another. By knowing the facts above, I can say that the spirit of nationalism of Indonesian youth has gone. They forget that the Indonesian youth revolutionary heroes had fought for unity to achieve Indonesia independence. I think it is important for Indonesian youth to understand the history of Indonesia Therefore, the main topic on my screenplay is the lack of nationalism spirit of young generation in Indonesia (Metrotvnews.com, 2015).

I use fantasy and adventure genres on my screenplay because these genres always captivate and mesmerize me. According to Guibernau, adventure stories are dominated by action which involves risk and excitement. It happens in exotic places and changes the hero (Dewan, The 
Adventure Genre, 2015). Also, fantasy genre is a genre where the main character will experience fantasy element, such as she makes a teleportation (Dewan, The Fantasy Genre, 2015). I have an inspiration to combine these genres from my favorite movie which is The Hobbit and Harry Potter and etc. As Karina Fabian, an American non-fictional writer and a writing online teacher, says that because "far-flung adventures with a lot of excitement and an element of the fantastic where the hero is pitted against an outside threat and must become a better person/creature in order to emerge victorious" interest her (Writing-world, 2009). In order to have a good screenplay, I use the adventure and fantasy's genre codes by Pauline Dewan. It helps me a lot to compose my screenplay.

Through my screenplay, I would like to send a message to Indonesian youngsters that we need to appreciate history and have the same spirit as the revolutionary heroes did by making a screenplay. I decided to choose film as the medium of reaching my goal because of two reasons. At first, film is one of the mass media in delivering idea, notion, and concept which effects the changing of society. Nowadays, film is the most appealing entertainment which is enjoyed by children and adults alike. By watching films, people may get entertained yet educated. People will interpret the message based on the connection between their background and the situation in the film. A good film may be able to change people's perception and eventualy it may change a society, for example, The Day After Tomorrow, The End of The Line, Blackfish, etc (Weforum, 2016). In addition, film may enhance moral responsibility, spread information, provide entertainment and at the same time builds motivation, innovation, creativity, and so on. The second reason is that the interest of Indonesian youngsters of reading books is decreasing. In 2012, UNESCO records that the interest of reading books of Indonesian people is 0.001 . It means that in every thousand people in Indonesia, there is only 1 person who has the interest of reading books. In addition, UNDP (United Nations Development Programme) releases the survey that Indonesian people is lower than Malaysian in melek huruf or literacy. It says that Indonesia has $65.5 \%$ while Malaysia gets higher, $86.4 \%$ ("Membaca Sebagai Jendela", 2015). By those facts, while the need to improve Indonesia's level of literacy, I believe that film may become the right medium for delivering message for Indonesian people at the moment.

I dedicate my screenplay for youngsters in Indonesia. The reason behind it is because children are part of young generation that will be leading the future of Indonesia. The vice head of People's Consultative Assembly of Indonesia, Mahyudin, said that nationality insight should be implemented in the early age to prevent the loss of Indonesian identity to young generation (Beritasatu.com, 2015). In addition, filmmakers for Children movies are limited compared to filmmakers for adult movies. Most films that are screened in cinemas are for adult consumers. The proof is that films with drama romance genre dominate the cinema now, such as Magic Hour and Love You ... Love You Not (Bintang, 2015). Also, according to FilmIndonesia.co.id, the films that are showing in cinema now are 3 Dara, 3 (Tiga), Demona, Dihantui Guna-Guna, Komedi Moderen Gokil, Magic Hour, Malaikat Kecil, The Wedding \& Bebek Betutu, Where Is My Romeo. Those films can mostly be watched by adult. There are children films about nationalism, such as Garuda di Dadaku, Hasduk Berpola, Denias, Senandung Di Atas Awan (Film Indonesia, 2015), however, they are limited in number. In order to serve Indonesia, I would like to help Indonesian children to resurrect the spirit of Indonesian revolutionary heroes.

During my creative process, I do a research through collecting primary and secondary research data to help me composing my story. The primary data is data taken from an observation in Majapahit Hotel. On 30 October 2016, I observed the hotel to get more accurate information about the history of the hotel. From the observation, I get some locations I can use in my story. Therefore, I get a location named Room 33 where the negotiation between General Sudirman and Mr. Ploegman happened. In addition, another primary data is data taken from a voice recording of Bung Tomo's speech. Secondary data is data taken from books, official statistics and reports, or mass media (Sugiyono, 2008). Therefore, I use data from certain articles such as Detiknews online and Kompas online. Also, I use some information from videos of official website such as, Liputan6 and Metrotvnews website. Then, through these secondary data research, I find an issue about the spirit of nationalism of young generation in Indonesia. I see that Indonesian young generation has not found their identity as Indonesian generation. Next, for some theory, I take some secondary data from the educational site of Pauline Dewey. I also get factual data through some articles in official online 
news paper such as Detiknews and Kompas online news paper. For some theories, I take the data from several books.

\section{DESIGN CONCEPT}

The theme of my creative work will be a journey of Dahlia to pursue her spirit of nationalism with inspired by the youth Indonesian revolutionary heroes. As I explained before, Indonesian youngster's spirit of nationalism has been decreasing. They lose interest to contribute themselves to develop Indonesia. They just enjoy the freedom of Indonesia from colonization. They become separate and think about themselves. In the story, Dahlia will experience the atmosphere of living in the middle of the battle of Surabaya and Yamato Hotel incident. She will experience how fierce and scary the youth Indonesian revolutionary heroes to fight for Indonesia in the battle. Also, she will experience that Arek-arek Suroboyo undoubtedly sacrifice their life to defend Indonesia independence. She will learn that as Indonesian youngsters, she has to maintain the spirit of nationalism for Indonesia.

Through those experiences, Dahlia will know history of Surabaya and starts to like history of Indonesia that makes her sure about her identity as Indonesian youngster. She will be Indonesian youngster who love her country better and encourages her friends to do so. In addition, she also learn that youth heroes in Surabaya at that time are not only coming from Javanese, but also other group of ethnics which can encourage her friend to become on to improve Indonesia.

In every screenplay proposal, there are three sentences which covers the whole story in a screenplay. The three sentences are called pitch. Below, I am showing the pitch of my screenplay.

a. Dahlia has no concern to Indonesia because she was born and grown up in Australia. She is given an assignment about heroic history happened in Indonesia. She finds the assignment is difficult, so she asks for help to her grandfather.

b. During her holidays, she plans to do her assignment but, she is trapped between the present and past life. She witnesses some heroic events in the past.

c. Dahlia loves her country better and encourages her friends to love Indonesia better by performing a theatre.

From this pitch, I can develop it into my draft that I create for my screenplay writing.

\section{SYNOPSIS}

The story is about Dahlia, a 13 year-old girl, who has parents both Indonesian but, she was born and lived in Australia. It is because her father pursues education for bachelor 2 and gets a job in Australia. Because of that, she loves Australia over Indonesia. She does not know anything about Indonesia. Once, she is given assignments for holidays about heroic history of Indonesia. She finds it is difficult and asks her father. Her father tells her to ask about it to her grandfather who lives in Surabaya. Dahlia spends her holidays in Surabaya in order to visit her grandfather and grandmother's grave at the same time. As she visits her grandfather, she asks him about the heroic history of Indonesia, but her grandfather does not tell her anything and gives her a classic wrist-watch instead. There the journey of Dahlia begins.

After visiting her grandfather, Dahlia and her parents stay at Majapahit Hotel Surabaya. In there, she sometimes sees some Caucasian and uniformed man and hears the voice of people shouting, screaming, and the step of bunch of people running. Unconsciously, she makes a teleportation to the past life. She meets Rini and her family, also Heri. She thinks it is a dream until Rini tells her that it is a real. Because she can make a teleportation back and forth, she uses the chance to witness Indonesia heroic history. Finally, she knows the heroic history of Surabaya. She witnesses the ripping of Dutch flag in Yamato Hotel event and the battle of Surabaya (10 November incident). After witnessing those histories, she tells about it to her grandfather. Unexpectedly, her grandfather tells that her friends in the past life are him and her grandmother when they were a child. She is surprised and thankful to meet her very young grandmother and grandfather. Finally, she gets to know and like about Indonesia history. Also, she gains the spirit of loving Indonesia better by learning about what the youth Indonesian revolutionary heroes had done in the past for Indonesia. Another important thing is that she can encourage her friends to love Indonesia better. 


\section{CONCLUSION}

After a long process, finally I finish my project which is writing a screenplay. This is my first time in writing a screenplay on more than thirty pages. I find it very difficult yet interesting. During the process of writing my screenplay, I learn that history is important and Indonesian youth is the agent of change. Also, I learn the technical of making a screenplay.

First of all, I learn that history should not be forgotten. Indeed, history teaches important things to do better in the future. I think that Indonesia has many great histories which can help its nation to realize how difficult to achieve a freedom. For example, from my story, a history of Indonesia which is known as Yamato Hotel incident make Dahlia realize that the heroes were very brave to fight with colonizers in order to achieve their freedom again. They were willing to go to war and sacrificing themselves to fight with colonizers even though they knew that their weapon was not enough to beat the colonizers. From this history, people should appreciate what the heroes had done and copy their spirit to face Indonesian's problems nowadays and to improve Indonesia.

Second, after knowing about history of Indonesia, Indonesian people will realize that the one who has high energy and spirit to improve Indonesia are Indonesian youth. Only Indonesian youth has energy and spirit to fight for Indonesia better. They know that they are the agent of change, so the youth from all over Indonesia can realize that they need to working as one in order to improve Indonesia. In my story, Dahlia realizes that she has to encourage her friends to love Indonesia so that she can work together to do something for Indonesia.

At last, I learn that in making a screenplay, I do not only start writing and end the story as much as I want, but writing a screenplay involves a creative process. I have to learn to make a strong character, use the right format of screenplay, and do research. A story needs a strong character because a strong character can attract people's attention and make people understand where the story is going to.Another thing that I learn is the format of screenplay. A screenplay has format such as slug lines, actions, dialogues, and etc which is different from scriptwriting. It is made to help the director in making a movie.If I make a wrong format, it can confuse the director. Also, I learn that in making a story, we do not only put what we know about something, but also we need to clarify anything that we will put in the story. To avoid wrong information and perception, I do some research about history of Indonesia from internet and e-books. Even, I observe directly in the place where it is called as the legacy of Indonesian's history.

After finishing this project, it enlightens me about what I am going to do next for my career. Graduated from English Department, especially in English for Creative Industry concentration, makes me decide to keep writing screenplay which the story itself about Indonesia in any kind of genres. There are many elements in Indonesia that can be made into a story. I find it interesting to make a story about Indonesia and I will learn Indonesia profoundly by writing a screenplay. Hopefully, the screenplay that I write will be sent to the house production in Indonesia and it will be accepted and make it into a movie. Also, it shows my perpetuation to Indonesia because my screenplay is dedicated to Indonesian people. Also, this screenplay is dedicated to International population in order to introduce original Indonesian story to them. If I can reach the Indonesian house production, then I will keep writing a screenplay and become a director of movie.

\section{REFERENCES:}

Bintang. (2015). Data Penonton 27 Agustus 2015, Film Drama Mendominasi Bioskop. Retrieved from http://www.bintang.com/celeb/read/2303175/data-penonton-27-agustus-2015-filmdrama-mendominasi-bioskop

Dewan, P. (2015, September 19). The Fantasy Genre. Retrieved 05 21, 2015, from Children's Literature Classics Discover the Wonder and Magic: The Fantasy Genre: http://childliterature.net/childlit/fantasy/

Dewan, P. (2015, September 19). The Fantasy Genre. Retrieved 05 21, 2015, from Children's Literature Classics Discover the Wonder and Magic: The Adventure Genre: http://childliterature.net/childlit/adventure/index.html

Khoiri, Ilham. (2015, May 19). Membaca Sebagai Jendela untuk Melihat Dunia. Kompas. Retrieved from http://print.kompas.com/baca/2015/05/19/Membaca-sebagai-Jendela-untuk-MelihatDunia 
Metrotvnews.com. (2015, October 26). Melawan Lupa: Kibarkan Api Semangat (3). Retrieved from http://video.metrotvnews.com/play/2015/10/26/444314/kibarkan-api-semangat-sumpahpemuda-3

Writing-world. (2009). Mixing It Up: Writing Across Genres. Retrieved from http://www.writingworld.com/fiction/crossgenre.shtml

Wanhar, W. (2015, October 29). Tempo Doeloe. Jawa Pos National Network. Retrieved from http://www.pojokpitu.com/baca.php?idurut=17137\&\&top=1\&\&ktg=\&\&keyrbk=Tempo\% 20Doeloe\&\&keyjdl=SUMPAH

Thomas, S. (2016, August 31). 10 Movies That Changed The World. World Economic Forum. Retrieved from https://www.weforum.org/agenda/2016/08/10-movies-that-changed-theworld/

(2015, September 13). Mahyudin: Wawasan Kebangsaan Perlu Ditanamkan Sejak Dini. Beritasatu.com. Retrieved from http://www.beritasatu.com/nasional/306585-mahyudinwawasan-kebangsaan-perlu-ditanamkan-sejak-dini.html 